УДК 619:616.995.1:599.735.52

(C) 2016

\author{
Мельничук В. В., завідувач навчально-наукової лабораторії паразитологї \\ кафедри паразитології та ветеринарно-санітарної експертизи, \\ Степанюк В. К., аспірант
}

(науковий керівник - доктор ветеринарних наук, професор В. О. Свстаф'єва)

Полтавська державна аграрна академія

\title{
ВІКОВА ДИНАМІКА СТРОНГІЛЯТОЗІВ ОРГАНІВ ТРАВЛЕННЯ ОВЕЦЬ НА ТЕРИТОРІЇ ПОЛТАВСЬКОЇ ОБЛАСТІ
}

\section{Рецензент - доктор ветеринарних наук, професор А. А. Замазій}

У роботі наведені дані щуодо рівня інвазованості овець різних вікових груп стронгілятами илунковокишкового тракту в умовах господарств Зіньківського, Шишацького, Кобеляцького районів Полтавської області. За наслідками копроовоскопічних досліджень встановлено значне поширення збудників стронгілятозів у овець (EI - 54,60\%) та доведений їх асоціативний перебіг із монієзіозом, еймеріозом, трихурозом, стронгілоїдозом. Найвищі показники екстенсивності та інтенсивності стронгілятозної інвазї (ЕI -

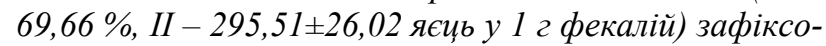
вано у молодняку овець віком від одного до двох років.

Ключові слова: вівиі, стронгілятози илунковокишкового тракту, поширення, вікова динаміка.

Постановка проблеми. Виробництво продукції вівчарства належить до економічно вигідних галузей тваринництва. Нині, за умов державної підтримки, вівчарство є досить перспективним для розвитку галузі з позицій підвищення ефективного використання землі, рівня зайнятості населення, забезпечення переробної та легкої промисловості незамінною сировиною та продуктами харчування. Крім того, вівчарство $є$ найменш енерговитратною галуззю $[7,11]$.

Вівці, як вид тварин, володіють високою адаптивною здатністю, що забезпечує можливість незначних витрат на їх утримання та використання для господарських цілей малодоступних земельних угідь. До плюсів також можна віднести велику різноманітність видів отримуваної продукції, що забезпечує високу сумарну ефективність використання поживних речовин корму [5].

У зв'язку з реорганізацією в сільському господарстві та створенням на селі багатопрофільних господарств, коли основне поголів'я овець зосереджене в подвір'ях, кооперативних, фермерських та селянських господарствах, проблеми боротьби 3 гельмінтозами набули особливої актуальності. Процеси, що відбуваються, негативно відбилися на епізоотичній ситуації щодо розповсюдження інвазійних хвороб овець $[4,9]$.
Аналіз основних досліджень і публікацій, у яких започатковано розв'язання проблеми. Одними 3 найбільш поширених інвазій овець $\epsilon$ стронгілятози органів травлення. Уражені збудниками інвазії тварини відстають у рості, різко знижується їх продуктивність (удій молока, настриг вовни, приріст живої маси, вихід приплоду), в окремих випадках за гострої форми захворювання загибель тварин сягає 60-80\% [1-3, 6, 8]. У зв'язку з цим питання вивчення вікової динаміки стронгілятозів кишкового каналу овець залишається таким, що потребує вивчення.

3 літературних джерел відомо, що над питанням шлунково-кишкових стронгілятозів овець більшою мірою працювали науковці Дагестану, Калмикії, Кавказу. За наслідками патологоанатомічних розтинів автори в своїх працях вказують на значне поширення цієї групи паразитозів (80-100\%) [4, 6]. В Україні бракує інформації щодо поширення та вікової динаміки стронгілятозів шлунково-кишкового тракту овець. Лише в окремих працях науковців $є$ короткі повідомлення існування даної проблеми $[1,2]$.

Мета досліджень полягала у вивченні вікової динаміки стронгілятозів шлунково-кишкового тракту овець на території Полтавської області.

У завдання досліджень входило вивчити поширення стронгілятозів органів травлення овець та встановити їх вікову динаміку.

Матеріали і методи досліджень. Роботу виконували в період 2015-2016 років на базі навчально-наукової лабораторії паразитології кафедри паразитології та ветеринарно-санітарної експертизи Полтавської державної аграрної академіï. Поширення стронгілятозів шлунковокишкового тракту вивчали в умовах приватних та одноосібних селянських господарств Зіньківського, Шишацького, Кобеляцького районів Полтавської області за наслідками копроовоскопічного обстеження тварин різних вікових груп: молодняку до 4-місячного віку, молодняку віком 


\section{ВЕТЕРИНАРНА МЕДИЦИНА}

від 4-х місяців до 1-го року, молодняку віком від 1-го до 2-х років та тваринах старше 2-річного віку. Копроовоскопічні дослідження проводили за кількісним методом В. Н. Трача [10], встановлювали кількість яєць у 1 г фекалій (ЯГФ). Основними показниками ураження овець були значення екстенсивності та інтенсивності інвазії (ЕI, II).

Результати дослідження. За результатами копроовоскопічних досліджень встановили, що інвазованість поголів'я овець збудниками стронгілятозів шлунково-кишкового тракту на території господарств Полтавської області в середньому становила 54,60 \%. Слід зазначити, що стронгілятозну інвазію у овець найчастіше реєстрували в складі мікст інвазій, співчленами якої були монієзії, еймерії, трихуриси та стронгілоїдеси (див. рис.).

Копроовоскопічними дослідженнями встановлено, що ступінь ураженості овець збудниками стронгілятозів шлунково-кишкового тракту залежав від їх віку (див. табл.).

3'ясовано, що з віком тварин показники екстенсивності та інтенсивності інвазії поступово зростають і дорівнюють відповідно: у молодняку

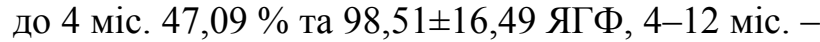

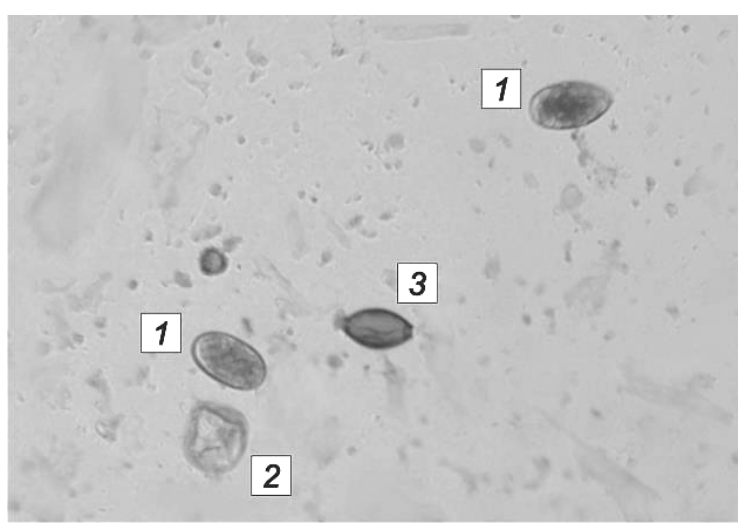

Рис. Яйця збудників стронгілятозів илунково-кишкового тракту овець (1) в асоціації з Мопіеzіа

sp. (2), Trichuris sp. (3), Strongyloides papillosus (4), Eimeria sp. (5)

Вікова динаміка стронгілятозів органів травлення овець

\begin{tabular}{|c|c|c|c|}
\hline Вікові групи овець & $\begin{array}{c}\text { Досліджено / } \\
\text { інвазовано, } \\
\text { голів }\end{array}$ & $\begin{array}{c}\text { EI, } \\
\%\end{array}$ & $\begin{array}{c}\text { II, ЯГФ, } \\
\text { M } \pm \mathrm{m} / \min -\mathrm{max}\end{array}$ \\
\hline Молодняк до 4-місячного віку & $172 / 81$ & 47,09 & $98,51 \pm 16,49 / 4-768$ \\
\hline $\begin{array}{c}\text { Молодняк від 4-х місяців до } \\
\text { 1-го року }\end{array}$ & $182 / 98$ & 53,84 & $170,75 \pm 15,06 / 4-1096$ \\
\hline $\begin{array}{c}\text { Молодняк віком від 1-го до } \\
\text { 2-х років }\end{array}$ & $178 / 124$ & 69,66 & $295,51 \pm 26,02 / 4-1660$ \\
\hline Вівці старше 2-річного віку & $228 / 112$ & 49,12 & $195,57 \pm 21,70 / 4-1640$ \\
\hline
\end{tabular}
муму в молодняку віком від 1-го до 2-річного віку (ЕI - 69,66 \%, II - 295,51 \pm 26,02 ЯГФ). У овець старших 2-річного віку показники інвазованості знижуються до $49,12 \%$ та $195,57 \pm$ 21,70 ЯГФ.

Отже, нами були отримані дані стосовно залежності показників EI та II за стронгілятозів органів травлення овець від їх віку. Доведено, що максимально уражався молодняк у віці від 1-го до 2-х років.

\section{Висновки:}

1. Встановлено, що стронгілятози шлунковокишкового тракту овець значно поширені на території Полтавської області (EI - 54,60 \%) і перебігають у складі асоціативних інвазій зі збудниками монієзіозу, еймеріозу, трихуроз, стронгілоїдозу.

2. Визначено, що ступінь ураження овець стронгілятами залежить від їх віку. Максимально ураженими були вівці віком від одного до

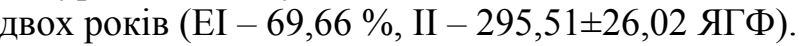

В подальшому планується вивчення сезонної динаміки стронгілятозів шлунково-кишкового тракту овець.

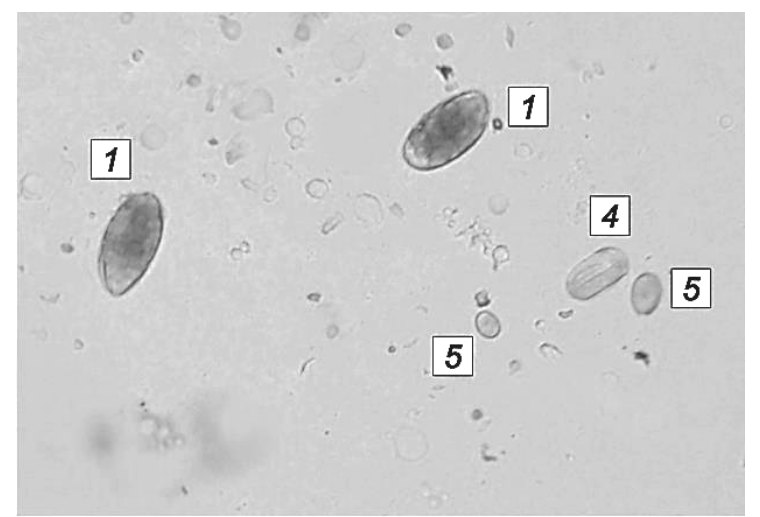




\section{БІБЛІОГРАФІЯ}

1. Власенко О.А. Епізоотологічна ситуація щодо інвазійних захворювань овець у господарствах Сумської області / О.А.Власенко, В. В. Стибель // Науковий вісник ЛНІВМ та БТ ім. С. 3. Гжицького. - 2012. - Т. 14. - №2 (52). C. 44-48.

2. Кльосов М. Д. Поширення і динаміка найголовніших гельмінтозів сільськогосподарських тварин у Запорізькій, Дніпропетровській, Полтавській, Вінницькій та Камінець-Подільській областях і в Молдавії / М. Д. Кльосов, С. А. Гнатюк, М. Я. Бекерман // Наук. праці. УІЕВ. - 1941. T. 10. - C. $127-158$.

3. Магомедов O. А. Экономический ущерб при экспериментальном эзофагостомозе овец / О. А. Магомедов, В. М. Шамхалов, Х. А. Ахмедрабаданов // Тр. Всерос. ин-та гельминтологии им. К. И. Скрябина. - Т. 44. - М., 2006. - С. 139-143.

4. Магомедов О. А. ЭПизоотология эзофагостомоза, буностомоза и нематодироза овец и меры борьбы с ними в Прикаспийском регионе : автореф. ... д.вет.н. : спец. 03.00.19 «Паразитология» / О. А. Магомедов. - М., 2007. - 46 с.

5. Мартишин О. М. Продуктивні якості гірськокарпатських і помісних овець різних варіантів схрещування в гірській зоні Карпат : дис. ... к.с.-Г.н.
: 06.02.01 / О. М. Мартишин. - Оброшино, 1993.$149 \mathrm{c}$.

6. Марченко В. А. Гельминтологическая ситуация в овцеводстве Горного Алтая / В. А. Марченко, Е. А. Ефремова, О. М. Бонина : материалы Международной научной конференции «Современные проблемы эпизоотологии». Краснообск, 2004. - С. 146-149.

7. Рябко В. М. Розвиток вівчарства на півдні України / В. М. Рябко // Вісник аграрної науки. 2002. - №4. - C. 39-41.

8. Сафиуллин Р. Т. Распространение и экономический ущерб от основных гельминтозов жвачных животных / Р. Т. Сафиуллин // Ветеринария. - 1997. - №6. - С. 28-32.

9. Сільське господарство України. Статистичний збірник. - К. : Державна служба статистики України, 2014. - $400 \mathrm{c}$.

10. Трач В. Н. Рекомендации по применению нового метода учёта яиц гельминтов и цист простейших в фекалиях животных / В. Н. Трач. - К., 1992. - 13 c.

11. Шелест Л. С. Оцінка стратегічного потенціалу вівчарства степової зони України : монографія / Л. С. Шелест. - Асканія-Нова, 2009. $164 \mathrm{c}$. 